STUDIA POLONIJNE

T. 40. LUBLIN 2019

DOI: http://dx.doi.org/10.18290/sp.2019.11

WOJCIECH SKÓRA

\title{
POLISH DIASPORA AND MILITARY INTELLIGENCE OF THE SECOND POLISH REPUBLIC, 1918-1939 AN OUTLINE OF THE PROBLEM
}

Polish diaspora, mainly understood as Poles permanently living abroad, formed the basis for Polish intelligence activities in the interwar period ${ }^{1}$. An analysis of selected intelligence networks and agents' nationalities may lead to such a conclusion. This phenomenon applied not only to "small fries" in the intelligence cycle, that is thousands of people gathering meaningless information, but also to the most prominent agents, who - although less often ${ }^{2}$ - were of Polish origin. In this regard, it is worth mentioning Paulina Tyszewska from Gdańsk ${ }^{3}$, Wiktor Katlewski ${ }^{4}$ from Berlin, and Bolesław Kontrym from the Soviet Union ${ }^{5}$. Thus, Polish community

Wojciech Skóra, PhD, Hab., Full Professor - Director of the Institute of History and Political Studies, Pomeranian University in Słupsk; e-mail: wojciech.skora@apsl.edu.pl

${ }^{1}$ In 1926, the Polish authorities estimated the number of Polish diaspora at 6 million people; these estimates had reached the number of 8 million individuals just before the outbreak of the World War II. However, these estimates were overstated.

2 Poles rarely held high-ranking positions in Germany or the Soviet Union, which was caused by the distrust in their loyalty. This situation occurred already during the partitions of Poland and had its roots in the aftermath of numerous national uprisings.

${ }^{3}$ Paulina Tyszewska (1899-1941), born in a Polish family, moved to the Free City of Danzig, where she became the life partner of the Deputy Head of the Abwehr outpost in Gdańsk, Commander Lieutenant, Reinhold Kohtz. Her recruitment in 1936 was a serious counterintelligence success for the Polish intelligence.

${ }^{4}$ Wiktor Katlewski (1910-1940), a German citizen of Polish nationality, was recruited by the Polish intelligence in 1934. In 1937, he began working at the Naval Weapons Department (Marinewaffenamt) of the German High Command of the Navy in Berlin. As an accountant he had access to calculations showing the development and state of arms, in particular, of this part of the armed forces. Katlewski and Tyszewska were sentenced to death by the Germans during the World War II. This occurred as a direct result of German actions after the discovery of the Polish intelligence archives in occupied Warsaw in September 1939.

5 Bolesław Kontrym (also known by codename "Żmudzin”, 1898-1953) was an officer of the Red Army when he offered his services to the Polish intelligence. Between 1920 and 1922, he delivered a number of valuable information about the Soviet Union. After escaping USSR with his family, 
played a key role in the clandestine struggle, often breaking the allegiance to the country of residence. Its members were usually guided by patriotism. The Polish state was relatively poor and therefore the intelligence was not able to gain the necessary means to recruit new agents for a risky cooperation by way of high remuneration. Emotional motivation was also needed, usually based on their fondness for the reborn homeland.

In the Second Polish Republic, intelligence activities abroad were conducted by the army. Generally, the goal was to obtain information concerning phenomena important for state security, their analysis, verification, and then transfer to military and civil authorities. This task belonged to the Second Department of the Main Staff (General Staff since December 1928). The organizational structure of the military intelligence in the country consisted of a Warsaw headquarters, field units (Independent Information Offices) located in large cities near the border (numbering several or a few dozen men) and subordinate officers' posts (PO).

Poland, in the interwar period, had two major opponents, threatening the sovereignty of the state, namely Germany as well as the Soviet Union. As a result, the Second Department actively operated against both these countries between 1918 and 1939. This was largely reflected in the organizational structure of its Warsaw headquarters, where Independent Information Offices "East" and "West" formed the core of intelligence structures. It may be regarded as certain that over $80 \%$ of the financial resources, personnel and intelligence information obtained were related to Berlin and Moscow.

Officers of the Polish Army stood at the heart of activities led by the Second Department. However, various agents, in other words people recruited for cooperation, were mostly responsible for acquisition of information on a given subject. These people remained in contact with their case officer and had to go through the trial period, sign a declaration of cooperation, as well as obtain valuable information. A typical agent received salary, code name and identification number.

The ability to recruit new agents is essential when it comes to successful intelligence activities. This capacity had been developed among European intelligence services at least since the beginning of the 19th century. However, effective enrollment of agents or informants depended mainly on the intuition and high level of the emotional intelligence of a given officer, notably on account of the fact that each recruitment process was different. One of Mossad's renowned officers outlined,

he worked in the ranks of the Polish police. During the war, he was active in the Home Army. Historians, however, consider that his cooperation with the Polish intelligence could be part of a disinformation operation against Poland, which was carried out by the Soviet secret services. See: W. PASEK, Bolesława Kontryma życie zuchwate. Biografia żotnierza i policjanta, Warszawa 2006. 
during the training courses, three main ways of recruitment, that is using one's desire to get rich, internal motives (e.g. affection for the homeland or vengeance) and $\operatorname{sex}^{6}$. Polish methods, and probably those employed by other secret services, were of similar nature. In summarizing the reports prepared by officers of the Second Department on the recruitment, it should be stated that there were four main reasons for cooperation, which are still valid today. First of them included patriotic feelings, the second - money (financial gains), the third - compulsion (acting under pressure exerted by the Second Department or other intelligence services, usually on indebted and unfaithful people), fourth - emotions of a recruited person stemming from his character (e.g. feeling of political bitterness, professional frustration, desire for new adventures). In both classifications the first positions overlap to a large extent: Poles, the largest group of informants of the Second Department, often cooperated driven by their patriotic feelings. The Germans called representatives of this group patriotischenSpions ${ }^{7}$.

Germany and the Soviet Union hosted a large Polish community. From the point of view of the Second Department, these enclaves constituted an obvious environment for the "enlistment of new agents". This phenomenon was all the more advantageous since most of them lived mainly in areas bordering Poland, that is the most important lands for the security of the state (Prussia in Germany, Soviet Byelorussia as well as Soviet Ukraine in the East).

According to the German census of 1925 , the local Polish community numbered 984,000 residents, of which 803,000 possessed German citizenship. However, the Polish authorities assessed that the number of Poles in Germany was much greater on the grounds of different criteria. The most frequently indicated numbers ranged from 1.2 to 1.7 million Poles. The largest groups of Polish diaspora lived in the eastern provinces of Prussia, where the population was indigenous ${ }^{8}$. The first census in the Soviet Union pointed out that the Polish community amounted up to 782,000 people (the vast majority living in Ukraine). The Polish authorities assessed that, in fact, the total number of local Polish diaspora reached 1.15 million residents. Certain estimates indicated a figure of almost 2 million Poles in the Soviet Union'. This may lead to the conclusion that the lands of the western and eastern neighbors, of particular interest for the Polish intelligence, were inhabited by a comparable, numerous group of people having a positive emotional attitude towards the Second

${ }^{6}$ G. Hoy, V. Ostrovsky, Wyznania szpiega. Z tajemnic izraelskiego wywiadu, Warszawa 1991, p. 94.

${ }^{7}$ M. Ronge, Kriegs- und Industrie-Spionage, Zürich-Leipzig-Wien 1930, p. 40.

${ }^{8}$ E. Kolodziej, Dzieje Polonii w zarysie 1918-1939, Warszawa 1991, pp. 15-17.

9 Ibidem, p. 76. 
Polish Republic, which could be used to obtain secret information. However, it was not an easy task, especially in view of the fact that the Soviet Union, right from the beginning, and Germany, since 1933, were totalitarian states with strongly developed structures of the secret police. In both countries, terror, widespread infiltration and negative attitude towards Poland, maintained by means of propaganda, hampered Polish intelligence activities. The governments in Berlin and Moscow were aware that their citizens of Polish origin formed the main recruitment base for Polish military intelligence and therefore used in-depth surveillance and terror against them, primarily in the East ${ }^{10}$.

Polish intelligence in the Soviet Union operated in extremely difficult conditions. A strict control over the society, exercised by the political police, was combined with an exceptionally efficient and ruthless communist counterintelligence. Polish diaspora in the Soviet Union was observed, intimidated, and finally subjected to a planned extermination in the 1930s (motivated by the fight against Polish espionage $)^{11}$. Nevertheless, the Second Department managed to maintain several intelligence outposts in the Soviet Union, usually operating undercover within diplomatic posts of the Polish Ministry of Foreign Affairs ${ }^{12}$.

In order to encapsulate the research regarding the composition of the Polish intelligence networks in the Soviet Union, Konrad Paduszek stated that the officers of the Second Department were specifically looking for "a contact, above all, with Poles or individuals of Polish origin living in a state ruled by the Bolsheviks"13. For members of the Polish community in the USSR, a frequent reason for taking the risk of collaboration with the Second Department was the hope of going back to Poland. Difficult living conditions in the USSR, such as poverty and terror, caused that there were plenty of volunteers. For instance, Wiktor Drobyszewski, Colonel of the tsarist army (and later on the Red Army), was recruited in 1923 by an officer

10 See: R. KUŚNIERZ, W świecie stalinowskich zbrodni. Ukraina w latach czystek i terroru (19341938) w obserwacjach i analizach MSZ oraz wywiadu wojskowego Drugiej Rzeczypospolitej, Słupsk 2013.

11 The Polish Operation of the Soviet security service 1937-1938 resulted in executions of approximately 111,000 Soviet citizens of Polish origin. Tens of thousands were deported from Soviet Byelorussia and Soviet Ukraine to eastern fringes of the Soviet Union. The crime was committed under the fictitious charge of conducting espionage and subversive activities for Poland. See: N. Iwanow, Zapomniane ludobójstwo. Polacy w państwie Stalina. „Operacja polska” 1937-1938, Kraków 2015.

${ }^{12}$ A list of Polish intelligence outposts in the Soviet Union is available through an on-line publication, see: Ł. Ulatowski, Polski wywiad wojskowy w 1939 roku. Struktura organizacyjna, składy osobowe, personel, budżet, mob., Warszawa 2013.

${ }^{13}$ K. PAduszek, Zajrzeć do mózgu Lenina. Wywiad II Rzeczypospolitej a postrewolucyjna Rosja, Łomianki 2016, p. 257. 
of the Second Department residing in Moscow, namely Władysław Michniewicz. An important role of the intermediary was played by another Pole, a young doctor, and at the same time a son-in-law of the Colonel, who worked in the Polish Delegation for Repatriation in Moscow. Drobyszewski worked in the Soviet Academy of the General Staff in Moscow and therefore was capable of gathering extremely valuable information. In the aftermath of a complicated intelligence operation, after the completion of the assigned tasks, the former agent Drobyszewski could freely walk around Warsaw wearing the uniform of an officer of the Polish Army ${ }^{14}$.

A similar procedure followed the recruitment of new agents by outposts of the Second Department in Lviv and Brest-Litowsk, which were involved in the so-called "shallow intelligence" in the Soviet Union (operating about $150 \mathrm{~km}$ away from the border, though often much further). The espionage networks, in most cases, consisted of Polish informants living in the borderland areas ${ }^{15}$. Polish special services used their poverty, patriotism and desire to obtain the right to return to Poland in order to convince them to collaboration. The latter escalated in the 1930s, when the Polish state increasingly defended itself against re-emigration from the USSR ${ }^{16}$. For many people of Polish origin, cooperation with the military intelligence created an opportunity to overcome this obstacle. Their hand-signed declarations of cooperation with the Second Department contained the following paragraph "On the part of the Polish Government, you are guaranteed... maintenance and assistance in your intelligence duties. In the event of being exposed, you are, hereby, provided with a position in the Republic of Poland, and thus your future

14 W. Michniewicz, Wielki bluff sowiecki, Chicago 1991, pp. 125-133.

${ }^{15}$ K. PaduszeK, Zajrzeć do mózgu Lenina, p. 275; K. Danielewicz, Lwowska ekspozytura wywiadu. Działalność Ekspozytury nr 5 SG we Lwowie w latach 1921-1939, Toruń 2011, p. 214.

${ }^{16}$ In January 1932, the Soviet authorities issued an order that forced various foreigners to provide themselves with passports of their native countries within the span of three months. This directive appeared as part of the "internal passporting" carried out in USSR at that time. Many former prisoners of war from the Austrian army, who were entitled to Polish citizenship, applied to Polish consular offices. Passports, however, were issued only to those who had a certificate stating that they were not citizens of the USSR, and to those who possessed a certified Polish citizenship, and finally to people who were not denied entry by Polish administrative authorities. The last issue turned out to be decisive. Polish administrative units, despite the confirmation of the right to Polish citizenship, often opposed repatriation. The reasons for that were connected with "communist beliefs", "subversive activities" or lack of means of subsistence in Poland. Such cases were deliberately prolonged in Polish consulates and in mid-1932, the Soviet authorities no longer issued documents certifying that local Poles were not Soviet citizens. Without these certificates, consular officials were in no position to issue passports. Those who failed to present these legal papers were "trapped" in the Soviet Union. See: W. Skóra, Stużba konsularna Drugiej Rzeczypospolitej. Organizacja, kadry i działalność, Toruń 2006, pp. 719-720. 
is safe" ${ }^{17}$. For an average representative of Polish diaspora in the USSR, these were tempting promises. On the other hand, penalties for espionage in that country were extremely severe.

As much as in the east, Polish intelligence also relied heavily on the Polish community in Germany ${ }^{18}$. Initially, the command of the Second Department did not oppose the recruitment of members and activists of Polish national organizations in Germany, or in general - representatives of the Polish minority in the Weimar Republic. On the contrary, in the first years of independence, it was obvious that they constituted the main reservoir of agents and informants. In the summer of 1922, the head of the Independent Information Office No. 3 in Poznań, Captain Władysław Zakrzewski, strongly advocated in favor of engaging Polish organizations in Germany in the intelligence activities and tried to persuade the representative of the Polish Legation in Berlin to follow his plan ${ }^{19}$.

The aforementioned approach, however, changed in 1924. This was caused by the formation of the Union of Poles in Germany $(\mathrm{ZPwN})$ that took place two years earlier and the Germans' reactions to the consolidation of the Polish national movement. Emerging structures of the $\mathrm{ZPwN}$ had to avoid the label of "the nest of Polish espionage". Their members, especially the leaders, had to be beyond any suspicion. The headquarters in Warsaw was aware of the fact that the possible disgrace of a developing organization would be much more harmful than problems surrounding the recruitment of intelligence informants. The documentation of the Second Department shows beyond doubt different instances of officers being forced to abandon recruitment within the structures of Polish diaspora organizations in Germany. In 1924, the head of the Independent Information Office No. 3 in Poznań, Major Marian Steifer, instructed the activist of the Union of Silesian Insurgents to recruit several agents ready to operate in Upper Silesia. For this reason, he left him with a large sum of money and decided to give him free rein. When the news reached the intelligence headquarters in Warsaw, Major Steifer was informed that "The recent rulings of the Reich Court in Leipzig have clearly demonstrated that intelligence

${ }^{17}$ K. Paduszek, Zajrzeć do mózgu Lenina, p. 277.

${ }^{18}$ For more information, see: W. SKóRA, Polacy $w$ Niemczech jako wsparcie działań wywiadu wojskowego Drugiej Rzeczypospolitej (wybrane problemy), [in:] Bezpieczeństwo państw a procesy migracyjne, red. L. Kacprzak, J. Knopek, Piła 2008, pp. 171-190.

${ }^{19}$ If such an attitude was openly expressed by the officer deciding about the work of one of the most important intelligence outposts responsible for the intelligence in Germany, it can be concluded that back then the command of the Second Department accepted this kind of standpoint (Archiwum Akt Nowych [AAN: Central Archives of Modern Records], Ambasada RP w Berlinie [Embassy of the Second Polish Republic in Berlin], file no. 3657, Letter to the Counselor of the Polish Legation in Berlin concerning military intelligence in Germany, 17 August 1922). 
activities conducted with the help of our own minority in a given country, at the price of negligible benefits, will result only in serious losses for the Polish diaspora in the area". Therefore, the Second Department forbade its officers to engage Polish activists in intelligence gathering ${ }^{20}$. Later, the ban was repeated several times because certain intelligence officers tried to avoid this regulation. Collaboration with Polish national activists, such as Masurians, Silesians and Kashubians, who were guided by patriotism, was too valuable to simply give it up.

The May Coup of 1926 strengthened position of the army in the structures of the state. In addition, one of its causes was the marked deterioration of Poland's international position. The high command of the special services was even more determined to compete with Germany on the international stage. After 1926, officers of the Second Department, on numerous occasions, enrolled activists of Polish national organizations in Germany without any opposition on the part of their superiors ${ }^{21}$. However, in the late 1920s, the Second Department admonished its officers conducting intelligence in Germany, so that activists of Polish national organizations would not be involved as agents. The ban, nevertheless, was narrowed down to presidents, secretaries and board members of these organizations. In the recommendation of 1929, a significant supplement was added that "in exceptional cases" even prominent activists can be recruited, but this process must have been preceded by a fully motivated proposals, which were then considered by the Warsaw headquarters of the Second Department ${ }^{22}$. There was also a clear tendency to alleviate strict orders.

After the rise of the Nazis to power in Germany in 1933, the recruitment of Polish diaspora in German Reich was perceived as an acceptable practice. This resulted from intensive expansion of the German armed forces, general deterioration of the international situation, and as a consequence deterioration of Poland's security. The need to expose the opponent's weaknesses became ever more apparent. The

${ }^{20}$ Centralne Archiwum Wojskowe (CAW: Central Military Archives), Oddział II Sztabu Głównego (Oddział II: Second Department of Polish General Staff), file no. I.303.4.5872, Letter from the Intelligence Department of the Second Department to Independent Information Office No. 3 in Poznań, 27 December 1924.

${ }^{21}$ In 1929, for example, ZPwN activist and representative of the Kashubians in German regional council, Antoni Schröder, was recruited. See: W. SkórA, Placówki wywiadu polskiego w Chojnicach. Przyczynek do dziejów Pomorza Zachodniego i Nadwiślańskiego w dwudziestoleciu międzywojennym, Chojnice 2012, pp. 149-152.

${ }^{22}$ Archiwum Państwowe w Gdańsku (State Archive in Gdańsk), Komisarz Generalny RP w Gdańsku (General Commissioner of the Republic of Poland in Gdańsk), file no. 1690, Letter from the head of the Gdańsk Information Office (BIG), Captain Żychoń, to the subordinate officers' posts, 16 July 1929. Captain Zychon also decided - executing the command of the Second Department's headquarters - not to enroll those Poles-German citizens, who could be considered "as a reserve mobilization", that is intelligence agents activated in the event of the outbreak of the Polish-German war 
instructions of the head of Independent Information Office No. 3 in Bydgoszcz, published in 1933 and aimed at subordinate officers' posts, contained a detailed description of possible agents that should be recruited in German Reich. Captain Zychoń refrained himself from forbidding his officers to enroll Poles. The issue of the nationality of secret collaborators had not been addressed at all. Probably, this concern was considered to be marginal. The main emphasis was put on professionalism, intellect and contacts of potential informants ${ }^{23}$. Major Tadeusz Szumowski, head of Polish intelligence in the Third Reich between February and August 1939, stated during the war that "The intelligence network in Germany from 1938 to 1939 was retentive and actually the only one among the allied networks that functioned efficiently. The organization of this network began after the liquidation of Sosnowski. It was based on consulates, where officers of the Second Department worked under the guise of contract consular officials, having their own networks composed of local agents. Furthermore, the Polish minority was often used for these tasks [emphasis - W.S.]. Professional work was of a high standard, which was obvious when we exchanged our information with the French and the British before the war; we gave them exact information, and they generally could not find anything more important themselves" 24 .

The composition of intelligence network operating in north-eastern Germany in the 1930s was a clear indication of the fact that previous bans, issued after 1924, had already been abandoned and that the practices from the beginnings of Polish independence were reinstated yet again. In 1935, the Polish Consulate in Szczecin hosted an intelligence outpost with the code name "Bombaj". The post was managed by one of the most capable intelligence officers of the younger generation, Lieutenant Wacław Gilewicz. His informers formed a diverse group in terms of occupational status and place of residence. Nevertheless, they were quite homogeneous in terms of nationality, because the vast majority of them had Polish roots. In conclusion,

${ }^{23}$ CAW, Oddział II, file no. I.303.4.6133, Plan and guidelines of activities for officers' posts subordinate to Independent Information Office No. 3 in Bydgoszcz of the Second Department, 4 February 1933.

${ }^{24}$ Instytut Polski i Muzeum im. gen. Sikorskiego w Londynie [The Polish Institute and Sikorski Museum in London], Ministerstwo Spraw Zagranicznych [Ministry of Foreign Affairs], file no. A.11E.144, Report from the testimony of Major Tadeusz Szumowski before the commission appointed in connection with the result of the 1939 war campaign, 16 June 1943. It should be noted, however, that the key phrase from this passage was changed in the testimony report by a handwritten note. If this change is taken into account, the meaning changes significantly. The word "often" was crossed out and replaced by "to a small extent". It seems that Major Szumowski, after reviewing the protocol, wanted to change the original, spontaneous version. Regardless of which version to adopt, it is important that head of the Polish intelligence in Germany acknowledged the fact that the Polish minority in this country was engaged in espionage by the Second Department. 
after two years of creating a network of informants in Western Pomerania, East Prussia and Brandenburg all agents of the "Bombaj" outpost were Poles, one of them (Maksymilian Golisz) was a well-known national activist as well as teacher. Out of ten known candidates for agents, only two women were not of Polish origin. Among eight informants, fully aware of their duties, only two persons had nothing in common with Polish diaspora. Over $83 \%$ of agents working for the "Bombaj" outpost were Poles, including several people who could be considered as national activists ${ }^{25}$. This composition was not accidental and therefore reflected ongoing changes in the Polish intelligence headquarters in Warsaw. It is worth mentioning that every instance of recruitment needed a separate consent expressed by the supreme command of the Second Department. The command of Polish intelligence was fully aware of people used to create intelligence networks of separate outposts

Intelligence activities against German Reich and Soviet Union involved several outposts of the Second Department that were located in neighboring countries (France, Denmark, Sweden, the Baltic States, China and elsewhere). In 1936, the intelligence post codenamed "Tulipan", located at the Polish Consulate in Amsterdam, was headed by "consular official", Captain Feliks Mrozowski ${ }^{26}$. His tasks included observation of German affairs in the Netherlands, surveillance of the DutchGerman border in terms of free crossing, and the recruitment of a network of agents in the event of the Polish-German war. Since Poland was in good relations with the Netherlands, he was not forced to act in total conspiracy. The whole seven-member consulate staff knew about the real nature of Mrozowski's work. Two permanent informants worked for the officer (Pole and Dutchman) and three agents (all of them were of Polish origin, namely a contract official of the Polish Legation in The Hague, an interpreter and a law student) ${ }^{27}$.

Not all countries were suitable for developing intelligence networks based solely on members of Polish diaspora. The outpost of the Second Department (codenamed "Jur"), which was located in Budapest since 1936, used mainly Hungarians, Slovaks and Germans for its operations. Their task was to create a network of informants in case of the Polish-German war as well as provide valid information from the German Reich. Poland recognized Hungary as a friendly country and therefore Captain Roman Królikowski, head of the "Jur" outpost, based in Polish Consulate and Legation was not allowed to investigate Hungarian army and

${ }^{25}$ CAW, Oddział II, 1775/89/158 (former file number), Organizational report of the "Bombaj" intelligence outpost in Szczecin, May 1937.

${ }^{26}$ Edward CzYŻEwSKI (1893-1986) was a full-time employee of the Ministry of Foreign Affairs since 1928. After leaving Amsterdam in 1936, he became head of the Polish Consulate in Kwidzyn, where he organized an intelligence outpost codenamed "Federer".

${ }^{27}$ CAW, Oddział II, file no. I.303.4.2355, Inspection report of the "Tulipan" outpost, 1937. 
industry. Poles in Hungary formed a small community. However, they were also expected to perform various assignments during the war. In the autumn of 1936, Captain Królikowski prepared a list of Polish citizens living in Hungary and Poles possessing a Hungarian citizenship, that is representatives of Polish diaspora, in order to select a dozen or so "trusted and reliable" individuals who in case of military conflict would be activated as agents for communication and intermediation with previously recruited Hungarian informants. Królikowski selected persons working mostly for the Polish-Hungarian Association ${ }^{28}$.

The tendency to build intelligence networks upon engagement of Polish community was permanent and could also be traced during the World War II. This way of intelligence gathering was simply convenient, effective and inexpensive. At that time, Polish secret services operated on a global scale, although its headquarters was (just like the government) in exile, initially in France and then in London (from 1941)

In 1941, the command of Polish special services created an intelligence outpost codenamed "Estezet", secretly located at the General Consulate of the Second Polish Republic in New York. Based on the initial assumptions, its area of activity was supposed to include the Third Reich, Polish allies and occupied countries, the Soviet Union, as well as area encompassing both Americas. In reality, however, its activity was limited to the United States of America, Canada and selected countries in South America, where apart from the central post in New York, several subordinate intelligence outposts were established. The main objectives of "Estezet" post were aimed at obtaining information on armed forces and internal situation of the Axis powers, as well as conducting offensive counterintelligence aimed at volunteers ready to join the Polish Army (Polish secret services strove to block the conscription of agents of enemy countries to the army). The more specific duties, among others, included "discreet surveillance of the situation in the both Americas, and in particular their efforts and preparation for war", observation of Polish diasporal communities and the prevailing moods among Polish Jews, Ukrainians, Lithuanians, Czechs and Slovaks $^{29}$. Regardless of cooperation with the intelligence services of the Allies, "Estezet" and its subordinate posts were operating in conspiracy ${ }^{30}$.

${ }^{28}$ CAW, Oddział II, file no. I.303.4.2320, Report on the operation of the "Jur" outpost in Budapest from 1 July until 30 September 1936.

${ }^{29}$ Instytut Józefa Piłsudskiego w Nowym Jorku [IJP NY: Józef Piłsudski Institute of America], Ekspozytura „Estezet” [Intelligence outpost “Estezet”], file no. 701-111-001-006, Organizational instruction and work plan of the outpost codenamed "Estezet" of the Second Department of the Supreme Commander's Staff and its intelligence post, 1941.

${ }^{30}$ According to orders intended for the subdivision of the "Estezet" outpost operating at the Consulate of the Second Polish Republic in Pittsburgh, headed by Mieczysław Żarski, "The post op- 
In the organizational report of the "Estezet" outpost for the last quarter of 1942 the recruitment of new agents was recapitulated. Nearly all of them were representatives of the Polish diaspora, namely a journalist and lawyer Franciszek Nahurski (American citizen, Polish minority activist in Minneapolis, president of the Slavic Association), Wacław Orzelski (Polish citizen living in the United States for many years), a journalist Antoni Skupień (Polish citizen living in Argentina for 36 years), Ludwik Krotoszyński (Polish citizen living in Paraguay), Włodzimierz Radomski (Polish activist in Curitiba). The only informants of non-Polish origin included Józef Konusz (codename "Joe"), Slovak, however "a friend of Poland, to which he relates with enthusiasm" and Carlos Carrasco (Uruguayan journalist) ${ }^{31}$.

Millions of Poles living outside of their native lands, that is members of Polish diaspora, were recognized by the Polish authorities as a reservoir of strong support for the homeland. The Polish Ministry of Foreign Affairs conducted activities aimed at turning them into a useful tool in the hands of the government. Wiktor Tomir Drymmer, largely responsible for various issues involving Polish diaspora in the Ministry of Foreign Affairs, concluded in 1934 "There is a fight for extending Poland beyond the political borders of the state" 32 . Unprecedented involvement of the Polish community in the activities of Polish intelligence services indicates that similar operations were conducted by the Second Department.

\section{BIBLIOGRAPHY}

\section{Archival materials}

Archiwum Akt Nowych (Central Archives of Modern Records)

Ambasada RP w Berlinie (Embassy of the Second Polish Republic in Berlin)

Ambasada RP w Paryżu (Embassy of the Second Polish Republic in Paris)

Archiwum Państwowe w Gdańsku (State Archive in Gdańsk)

Komisarz Generalny RP w Gdańsku (General Commissioner of the Republic of Poland in Gdańsk)

Centralne Archiwum Wojskowe (Central Military Archives)

Oddział II Sztabu Głównego (Second Department of Polish General Staff)

erates in conspiracy. Its existence and true nature should not be revealed to anyone, except the Consul and full-time officials of the consulate” (IJP NY, Ekspozytura „Estezet”, file no. 701-111-001-006, Instruction for the Intelligence Subdivision No. 1 of the "Estezet" outpost, 16 September 1941).

${ }^{31}$ IJP NY, Ekspozytura „Estezet”, file no. 701-111-002-079, Organizational report of the "Estezet" outpost for the last quarter of 1942.

${ }^{32}$ AAN, Ambasada RP w Paryżu (Embassy of the Second Polish Republic in Paris), file no. 283, Protocol from the first day of the consular meeting in Paris, held on 2-4 March 1934. 
Instytut Józefa Piłsudskiego w New York (Józef Piłsudski Institute of America) Ekspozytura „Estezet” (Intelligence outpost “Estezet”)

Instytut Polski i Muzeum im. gen. Sikorskiego w Londynie (The Polish Institute and Sikorski Museum in London)

Ministerstwo Spraw Zagranicznych (Ministry of Foreign Affairs)

\section{Published materials}

DANIELEwicz K., Lwowska ekspozytura wywiadu. Działalność Ekspozytury nr 5 SG we Lwowie w latach 1921-1939, Toruń: Wydawnictwo Adam Marszałek 2011.

Hoy G., Ostrovsky V., Wyznania szpiega. Z tajemnic izraelskiego wywiadu, Warszawa: Polus 1991.

IwaNOw N., Zapomniane ludobójstwo. Polacy w państwie Stalina. „Operacja polska” $1937-$ 1938, Kraków: Znak 2015.

KoŁodzIEJ E., Dzieje Polonii w zarysie 1918-1939, Warszawa: Książka i Wiedza 1991.

KUŚNIERZ R., W świecie stalinowskich zbrodni. Ukraina w latach czystek i terroru (19341938) w obserwacjach i analizach MSZ oraz wywiadu wojskowego Drugiej Rzeczypospolitej, Słupsk: Akademia Pomorska w Słupsku 2013.

Michniewicz W., Wielki bluff sowiecki, Chicago: WICI 1991.

PAduszeK K., Zajrzeć do mózgu Lenina. Wywiad II Rzeczypospolitej a postrewolucyjna Rosja, Łomianki: Wydawnictwo LTW 2016.

PASEK W., Bolesława Kontryma życie zuchwałe. Biografia żołnierza i policjanta, Warszawa: Fronda 2006.

RonGe M., Kriegs- und Industrie-Spionage, Zürich-Leipzig-Wien 1930.

SkóRa W., Placówki wywiadu polskiego w Chojnicach. Przyczynek do dziejów Pomorza Zachodniego i Nadwiślańskiego w dwudziestoleciu międzywojennym, Chojnice: Wydawnictwo Rys 2012.

SkóRa W., Polacy w Niemczech jako wsparcie działań wywiadu wojskowego Drugiej Rzeczypospolitej (wybrane problemy), [in:] Bezpieczeństwo państw a procesy migracyjne, red. L. Kacprzak, J. Knopek, Piła: PWSZ im. S. Staszica w Pile 2008.

SkóRA W., Służba konsularna Drugiej Rzeczypospolitej. Organizacja, kadry i działalność, Toruń: Wydawnictwo Inne 2006.

Ulatowski Ł., Polski wywiad wojskowy w 1939 roku. Struktura organizacyjna, składy osobowe, personel, budżet, mob., Warszawa 2013. 


\section{POLISH DIASPORA AND MILITARY INTELLIGENCE \\ OF THE SECOND POLISH REPUBLIC, 1918-1939}

AN OUTLINE OF THE PROBLEM

Sum mary

Millions of Poles living outside of their native lands, that is members of Polish diaspora, were recognized by the Polish authorities as a reservoir of strong support for the homeland. The Polish Ministry of Foreign Affairs conducted activities aimed at turning them into a useful tool in the hands of the government. Polish diaspora, mainly understood as Poles permanently living abroad, formed the basis for Polish intelligence activities in the interwar period. An analysis of selected intelligence networks and agents' nationalities may lead to such a conclusion. This phenomenon applied not only to "small fries" in the intelligence cycle, that is thousands of people gathering meaningless information, but also to the most prominent agents, who - although less often - were of Polish origin.

Key words: Polish diaspora; military intelligence; Second Polish Republic

\section{POLONIA A WYWIAD WOJSKOWY \\ DRUGIEJ RZECZYPOSPOLITEJ (1918-1939) \\ ZARYS PROBLEMU}

\section{Streszczenie}

Wielomilionowa Polonia była uznawana przez władze Polski za rezerwuar wsparcia dla kraju. Ministerstwo Spraw Zagranicznych prowadziło działania mające uczynić z niej narzędzie rządu. Polonia, rozumiana jako Polacy na stałe przebywający za granicą, była w dwudziestoleciu międzywojennym podstawą działań wywiadu polskiego. Do takiego wniosku prowadzi analiza wybranych siatek wywiadowczych i narodowości agentów. Nie dotyczyło to wyłącznie „agenturalnej drobnicy”, owych tysięcy osób zbierających drobne wiadomości. Również najważniejsi agenci - choć rzadziej - byli z pochodzenia Polakami.

Słowa kluczowe: Polonia; wywiad wojskowy; Druga Rzeczpospolita 